\title{
The Effect of Brand Perception in Malaysia's International Airline Industry During Covid 19
}

\author{
Dr. Kateryna Vorobyova* \\ Limkokwing University of Creative Technology, Malaysia \\ Submission: May 6, 2021; Published: June 14, 2021 \\ "Corresponding author: Kateryna Vorobyova, Limkokwing University of Creative Technology, Malaysia
}

\begin{abstract}
Nowadays consumers play a vital role in the company's income especially during Covid 19. The borders are closed and airline companies facing a huge downsizing regarding the performance. Hence, this current study caring the agenda of how the perception brand of the airline companies influences intention to purchase the airline ticket and actual customers purchase. Highlighted how consumers' behavior shifted during Covid19. The current research will clarify the information for the airline companies and will bring their attention to the performance. The conceptual model includes Brand attitude (brand association and brand belief), brand reputation (brand reliability, brand benevolence), brand experience (brand relationship-based experience). The result of the current research with 211 participants has shown a positive impact of brand attitude and brand experience on purchase intention. Subsequently, purchase intention with $\mathrm{R}(0.75)$ has a substantial value on actual behavior: Brand reputation has a negative and insignificant impact on purchase intention. The study suggests the airline companies should strategically manage the consumer attitude towards brand attitude along with association and brand belief, brand experience plays an important role in the consumer intention to purchase.
\end{abstract}

Keywords: Brand perception; Brand attitude; Brand reputation; Brand experience; Purchase intention; Actual behavior

\section{Introduction}

Nowadays, almost all of us experience flying with one of the airlines in the world. Almost every county has its airlines, some not just one but more. This marks how well the airline industry is growing tremendously in the modern era. Flying by plane makes it a lot easier now compared to the 70's era which airplane's ticket price are very expensive and not all class of income can afford it. That is the era where the only way to travel to the place that is separated by sea is by a ship which takes months sometimes to arrive at the said destination. By airplanes, a one-month trip can be shortened to a one-hour trip minus all the risk of bad weather and danger at the sea. Malaysia's airline industry has grown rapidly in the past 20 years. The airline industry in Malaysia is one of their sources of revenue. It generates thousands of job opportunities for Malaysians and expatriates in Malaysia. All airlines in Malaysia offer domestic flights inside Malaysia and only three of the Airlines offer international flights.

Consumer positive brand perception on a brand is the greatest asset for an airline, especially in today's competitive environment. Slight dissatisfaction may lead the airline to lose their potential customer. According to Archana and Subha [1] excellent passenger satisfaction is one of the biggest assets for an airline in today's competitive environment, the board experience is still something special for the customer. If the passenger is dissatisfied with the quality of service, they will reconsider the buying decision for further flights and will probably switch to another airline.

Several studies are conducted in other countries such as Evaluation of customer perceptions on airline service quality in uncertainty on China Air and Eva Air [2] and Brand Image and Brand Awareness- Case Study: Dubai Market [3] but none are the studies specific to Malaysia's Airline Industry. A better understanding of the brand perception that can lead to purchasing intention in Malaysia's International Airline Industry needs to be studied as brand function value relates to the ability of a brand to meet consumer's function needs and wants [4]. Every business needs to focus on impressing the consumers out there, and brand function is one of the key elements of successful branding. This study will find a connection between brand perception which includes brand attitude, brand reputation, brand experience, and its influence on purchase intention with subsequent actual behavior to the airline industry.

Brand reputation is one of the factors that need to be explored. Brands have historically concentrated on managing their function 
attributes, but it has been reported that they have neglected to pay adequate attention to managing the emotional qualities straightforwardly [5]. Most brands forget about brand reputation when they upgrade their services or product.

The credibility of a brand reputation is more important now than ever. Maintaining a good image for the brand increases customer satisfaction, creates trust in the market, and helps place a business in their market as a leader. Business can quickly boost their image with strategic brand reputation management strategies. The brand plays a critical role in creating the exposure and position of the organization in foreign markets [6].

According to Henderson I, Tsui K, Ngo T et al., [7], brand experience defines as subjective internal responses such as sensation, feeling, and cognition including behavioral responses by the brand-stimuli that are part of the brand function and design. Brand experience influence how customer post-reaction on their encounter for the brand services. From experience, the consumer learns either the brand is good or bad for them. Brand experience is a major contributor to consumer purchase intention, and it is important to maintain the business in a long-term period.

Brand interaction is one of the factors of brand perception in this study. Brand interaction is also known as brand engagement. Interaction defines as acknowledges not only by purchase interaction but pure exchange situation [8]. Brand interaction is important to establish two-way communication between the brand and consumers. It can be measured on how well the feedback by a customer is in the social media with a brand customer service.

All these brand perception elements will lead to purchase intention in the airline industry. They are important to make sure that the airline company can lead the market by fulfilling what the consumers want and need. But the connection between them is still unclear in many aspects. Therefore, the problem of this study is how does brand perception and leads to purchase intention and how both brand perception and purchase intention can be established in Malaysia's International Airline Industry.

The current study will extend the work by determining and understanding how brand perceptions influence purchase intentions of the consumers with following actual behavior to use specific airlines in Malaysia such as Air Asia and Malaysia Airlines. Although, the current study will make a comparative analysis of each airline brand. The significance of this study is to enhance our understanding of how brand perception can lead to purchasing intention behavior. Not everyone aware of what is brand perception is and they did not realize they are one of the contributors to brand perception in Malaysia. It is also important, especially to a consumer outside Malaysia on what is the brand perception by the local Malaysian here towards their airline. This will help them to understand the perception of the airlines themselves and help them to decide if they have a purchase intention in using any of Malaysia's airlines in the future. This study focuses on how Malaysian choose their airline depend on their wants and needs. To summarize the significance of the study.

i. This study benefits consumer outside Malaysia to understand Malaysia's Airline Industry

ii. This help consumer interprets and understands their brand perception towards Malaysia's Airline Industry

iii. This study will use as a guideline to future research on Malaysia's Airline Industry in Brand Perception and Purchase Intention

iv. This study also benefits the Airline Industry in Malaysia to understand more about consumer's perception regarding their company.

The structure of the research will be followed by literature review and hypotheses development, chapter three will be dedicated to the methodology, chapter four will be included analysis and conclusion with discussion.

\section{Literature Review and Hypotheses Development}

Brand perception is related to the ability of a brand to meet consumer's needs and wants [9]. Consumers are viewed as logical thinkers that involve in the reasoning process to purchase the best product or services out of all the alternatives available in the market based on their judgment on the function value $[10,11]$. Thus, it can be said that the function value that is claimed can provide a utilitarian reference to the features of a product along with the benefits and value generated from the features available and can generate consumer cognitive responses. According to Wang S [12] in their study related to "Do global airline alliances influence the passenger's purchase decision? function value exists after a consumer consumes or feels the product that creates perception utility via function, practical and physical attributes. In the airline industry, the function value is there to be one of the fastest transportations, but the value-added function will differentiate the airline from another. Therefore, brand perception is one of the important aspects of purchase intention in the International Airline Industry in Malaysia.

According to Seo E, Park J (2015) brand attitude defines as the benefit that comes from the feeling or state of association or believes that service generates. Brand association or brand emotion is design to induce the emotion, feeling, and sentiments of the consumer. Emotional branding is the process of forming a relationship between a consumer by provoking their emotions Chen C, Chang Y (2008) [13]. Emotional design is important to improve customer satisfaction in an organization's new product or service development [14]. Every service upgrade or service provided needs to be emotionally attached to the consumer either it is comfort, pleasure, happiness, feeling safe, or satisfaction. Emotional value needs to be always positive towards a brand, which will increase the customer's loyalty towards the brand 
$[7,15]$. In the airline industry, brand affective need to be more positive compared to another competitor to attract more consumers in a long run. Therefore, from the study, there is always a positive connection related to brand effectiveness to purchase intention in International Airline Industry in Malaysia either it is new or repetitive.

A great brand reputation shows consumers' trust in your brand and those consumers are confident to do business with you [16]. Brand reputations need to be kept positive all the time to win customer's hearts in the market to ensure the relevance of the business in the long term. Today, to enhance brand reputation and increase profit, the airline industry embraces the role of corporate citizenship and advocating corporate social responsibility [17]. According to Woo E, Kim YG [18], a favorable corporate reputation is the most intangible asset driving company performance in the business world. If the airline did not invest in their reputation build-up, the intangible assets can become liabilities very fast. Reputation also establishes by individuals relatively, thus it is linked to consumer subjective evaluation. Brand reputation is the best weapon in the competitive airline industry. The better the reputation, the more trust is building thus more revenue generated from it. Therefore, it enhances purchase intention in the International Airline industry in Malaysia.

According to Shen C, Yahya Y [19], brand experience is a totality of subjective, internal consumer responses, such as sensations, feelings, and cognitions that are awakened by brand-related stimulation. It is more to the interaction that happens to a person with the brand and experience is what a post-interaction outcome. Whether it is a good or bad one, depends on how to satisfy the customer with the brand's overall performance during one interaction. Brand experience is related to the instinct for popular branding literature such as the brand image, brand awareness, credibility, and equity. According to Chung YS, Feng CM [20], it is a multidimensional construct, happens when the consumer is exposed to the brand stimuli that they will keep in their memory in a long term. Brand reputation is the image that needs to be maintained from time to time, taking into consideration the maintenance of the best customer service. Therefore, the better the brand reputation, the more consumer will be attracted to the airline services, thus spark purchase intention in International Airline Industry in Malaysia.

\section{Brand attitude and Purchase intention}

Customers' perception regarding the product or service their buy or use including brand should be consistent and positive. Companies' signature influence desired attributes, which in turn add value to the reputation $[21,22]$. However, consumers view brands differently from their perception which can have a great impact by aroused association and beliefs, which in turn work as variables for creating reputation towards the brand. Over time the perception of consumers towards the brand can be changed, however, the attitude towards the company can remain the same.
If that happens, companies should focus on advertising, which can be helpful to raise strategic position to differentiate themselves and provide an above-average return. A successful brand should attract consumers' attention [23].

H1: Attributes towards brand attitude which depends upon association and belief impact purchase intention.

\section{Brand reputation and purchase behavior}

In the content of brand reputation, it is assuming that the brand effectiveness of the three airlines leads to the purchase intention of fellow Malaysian. According to Commsights (2019), Brand reputation is simply how a brand (a person or an organization) is viewed by everyone else. A great brand reputation shows consumers' trust in your brand and that consumers are confident to do business with you (Commsights, 2019). Therefore, we assume there is a positive connection between brand reputation and purchase intention. Thus, the third hypotheses are

H2: Attributes towards brand reputation which depends upon reliability and benevolence impact purchase intention.

\section{Brand experience and purchase intention}

In the content of brand experience, it is assuming that the brand experience of the three airlines leads to the purchase intention of fellow Malaysian. Brand experience is a type of experiential marketing that incorporates a holistic set of conditions created by a company to influence the feeling a customer has about a particular product or company name Rouse (2018), [24]. Brand experience is widely communicated from mouth to mouth or social media. Therefore, we assume there is a positive connection between brand experience and purchase intention. Thus, the fourth hypotheses are

H3: Attributes towards the brand experience which depends upon a brand relationship-based experience impact purchase intention.

\section{Purchase intention and Actual Behaviour}

Purchase intention for companies can be measured as the potential action of using the product or services [25,26]. To understand the consumer market for companies it is necessary to monitor purchase intention to modify or adjust the product provided, which enables the companies to improve the product sales or predict the consumers' retention of the particular brand [27] (Figure 1).

H4: Consumers' purchase intention towards the airline brand positively affects their actual behavior to buy the service.

\section{Methodology}

\section{Data collection and sampling}

The conceptual model of brand perception is based on brand perceptions, a brand attitude that includes a brand association, 
and brand beliefs, a brand reputation that consists of brand reliability and brand benevolence, a brand experience that contains relationship-based experience. Besides brand perception was added purchase intention as a mediator and assessed actual behavior. The model hypothesized that brand perception is significantly influenced purchase intention, and subsequently purchase intention positively influences actual behavior among consumers.

Conceptual Framework.

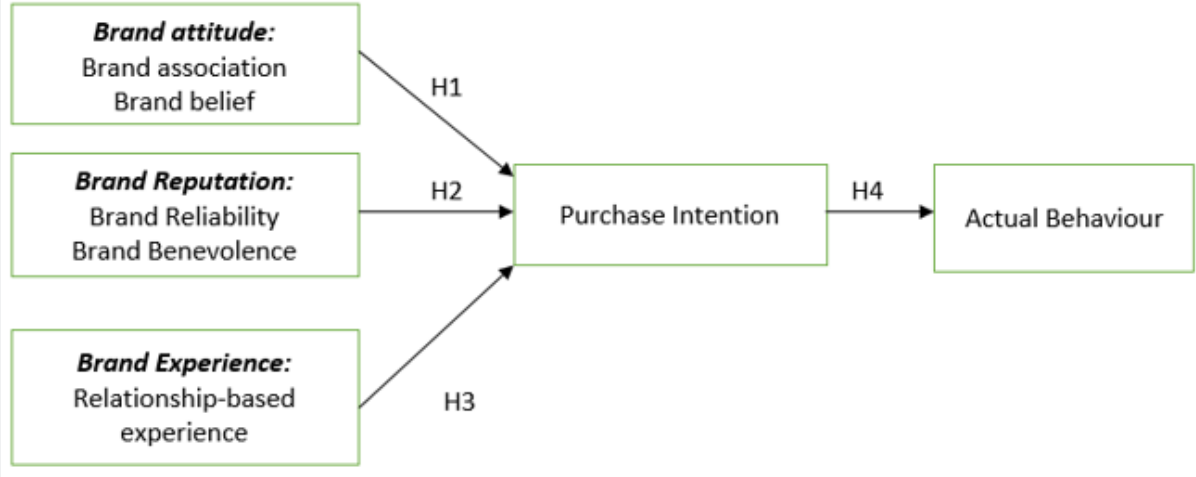

Figure 1: Conceptual Framework.

$\mathrm{H} 1$ : Attributes towards brand attitude which depends upon association and belief impact purchase intention.

$\mathrm{H} 2$ : Attributes towards brand reputation which depends upon reliability and benevolence impact purchase intention.

H3: Attributes towards the brand experience which depends upon a brand relationship-based experience impact purchase intention.

$\mathrm{H} 4$ : Consumers' purchase intention towards the airline brand positively affects their actual behavior to buy the service.

The data was collected using an online survey among people who are 18 years old and above, using two main airlines in Malaysia which are AirAsia, and Malaysia Airlines.

\section{Measurement}

The questionnaire was drawn from a previous study of brand attitude which includes 3 items [28-31]. Questionnaire related to brand reputation which includes reliability (four items) and benevolence (seven items) were adapted from Degado-Ballester and Luis Munuera- Aleman [32], DelVecchio [33]; Lombat and Louis [34]; Spears and Singh [35]; Sirdeshmukh et al. [36], Xie and Peng [37], Zhao and Roper [38]; Low and Ang [39]. Brand experience which contains four items were adapted from previous research $[40,41]$. Regarding purchase intention which was measured with three items, recommending, the intention of buying, and buying, following [42]. Actual behavior questions are related to buying the product, easiness, more convenience, and reliability and safety include four items and were derived from [43]. All questions were measures from 5-point Likers Scale with "1 Strongly disagree" to "5 Strongly agree" (Table 1).

The initial measures were subjected to a series of factors and reliability analysis as a preliminary test of their performance within the entire sample. The construct level reliability, also called "composite reliability" ensures that items assigned to the same construct reveal a higher relationship with each other. The appropriate measurement model involves examining the statistical significance of each factor loading and calculating the composite reliability. The scales are well above the commonly accepted requirements for reliability tests above 0.70 . $[44,45]$.

\section{Data Analysis and Discussion}

According to Hair et al., [44], the $\mathrm{N}=211$ is large enough to compensate for any model misspecification and model complexity. The quality and validity of the model were assessed in its unidimensional, reliability, convergent validity, and discriminant validity. All factors were assessed based on the basic principle components analyse performed on all constructs with items loading at 0.6 and higher. To support unidimensional crossloading was assessed and was not found significantly, thus can be concluded, that unidimensional for all factors was supported (Figure 2).

Model estimation delivers empirical measures of the relationships between the indicators and the constructs (measurement models), as well as between the constructs (structural model). The empirical measures enable us to compare the theoretically established measurement and structural models with reality, as represented by the sample data. In other words, we can determine how well the theory fits the data. Initially, the model assessment focuses on the measurement models. Examination of PLS-SEM estimates enables the researcher to evaluate the reliability and validity of the construct measures. Specifically, 


\section{Annals of Social Sciences \& Management studies}

multivariate measurement involves using several variables to indirectly measure a concept. The first criterion to be evaluated is typically internal consistency reliability. The traditional criterion for internal consistency is Cronbach's alpha, which provides an estimate of the reliability based on the inter $\urcorner$ correlations of the observed indicator variables. Cronbach's alpha assumes that all indicators are equally reliable (i.e., all the indicators have equal outer loadings on the construct). As has shown in Figure 3 Cronbach Alpha overcome the threshold of 0.7 , which is proving internal consistency reliability (Hair, et.al., 2014).

Table 1: Demographic statistics.

\begin{tabular}{|c|c|}
\hline & Percent \\
\hline \multicolumn{2}{|c|}{ Gender } \\
\hline Male & 55.6 \\
\hline Female & 44.4 \\
\hline \multicolumn{2}{|c|}{ Age } \\
\hline $18-23$ & 18.5 \\
\hline $24-30$ & 31.5 \\
\hline $31-39$ & 38.9 \\
\hline \multicolumn{2}{|c|}{$40-59$} \\
\hline \multicolumn{2}{|c|}{60 -above } \\
\hline \multicolumn{2}{|c|}{ Job } \\
\hline Student & 55.6 \\
\hline Education & 20.4 \\
\hline Service industry & 11.1 \\
\hline Financial industry & 9.3 \\
\hline \multicolumn{2}{|c|}{ Transportation } \\
\hline \multicolumn{2}{|c|}{ Reason to take the airplane } \\
\hline Business & 14.8 \\
\hline Travel/tourism & 53.7 \\
\hline Study & 31.5 \\
\hline \multicolumn{2}{|c|}{ Annual frequency to take a plane } \\
\hline Less than 1 time & 20.4 \\
\hline 1-3 times & 38.9 \\
\hline More than 3 times & 40.7 \\
\hline \multicolumn{2}{|c|}{ Who pays for the ticket } \\
\hline Themselves & 81.5 \\
\hline Company partly funding & 7 \\
\hline Company full funding & 13 \\
\hline \multicolumn{2}{|c|}{ Annual travel cost } \\
\hline Less than 2000MYR & 25.9 \\
\hline 2001 to $5000 \mathrm{MYR}$ & 46.3 \\
\hline 5001 to $8000 \mathrm{MYR}$ & 9.3 \\
\hline More than 8001 MYR & 18.5 \\
\hline \multicolumn{2}{|c|}{ Frequently reserved cabin } \\
\hline Economy & 94.4 \\
\hline Business & 5 \\
\hline First & 0.6 \\
\hline
\end{tabular}

Demographic profile of the consumers with the main population of 211 participants. $(\mathrm{N}=211)$. 


\section{Annals of Social Sciences \& Management studies}

Regarding Composite Reliability, as has shown in Figures 3, 4. all constructs meet the required benchmark which is exceeded the suggested 0.6 benchmarks [46].

A common measure to establish convergent validity on the con $\urcorner$ struct level is the average variance extracted (AVE). This criterion is defined as the grand mean value of the squared loadings of the indicators associated with the construct (i.e., the sum of the squared loadings divided by the number of indicators). Therefore, the AVE is equivalent to the commonality of a construct. Using the same logic as that used with the individual indicators, and AVE value of 0.50 or higher indicates that, on average, the construct explains more than half of the variance of its indicators (Figure 5) (Hair., et.al., 2014)

\begin{tabular}{lrrrr|} 
& Cronbach's Alpha & rho_A & Composite Reliability & Average Variance E: \\
\hline AB & 0.922 & 0.923 & 0.945 & 0.811 \\
BA & 0.885 & 0.909 & 0.909 & 0.562 \\
BExp & 0.819 & 0.850 & 0.879 & 0.646 \\
BR & 0.949 & 0.956 & 0.956 & 0.665 \\
PI & 0.758 & 0.759 & 0.861 & 0.674 \\
& & & \\
Figure 2: The first criterion to be evaluated is typically internal consistency reliability. & & \\
\hline
\end{tabular}

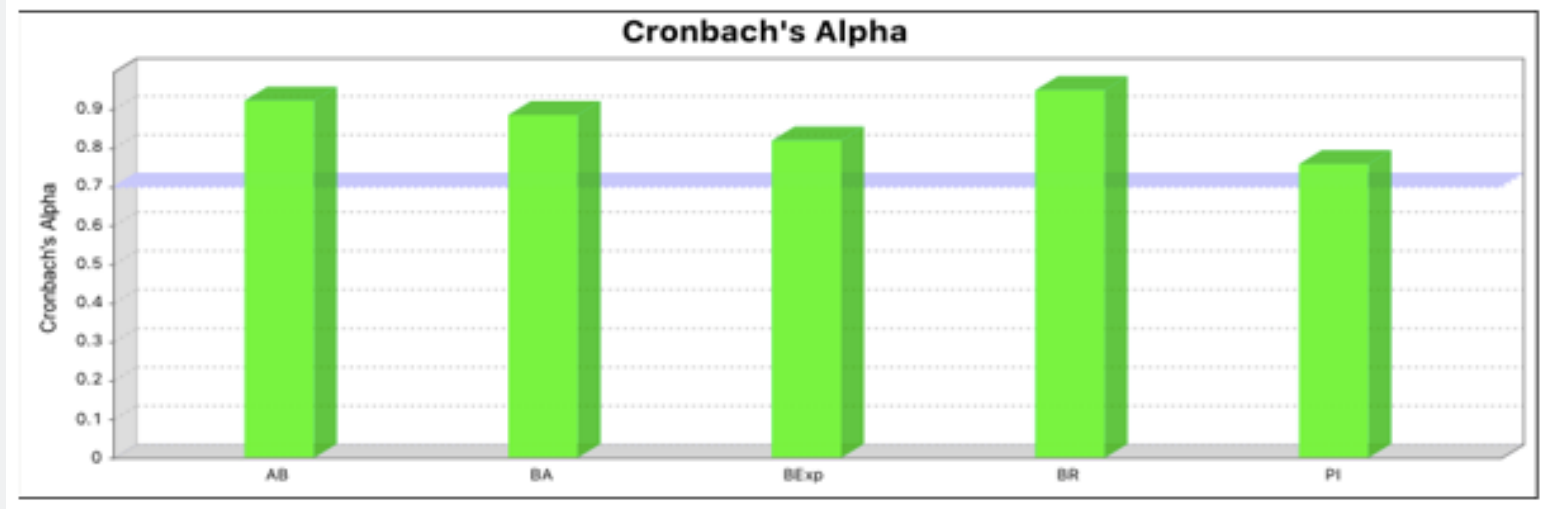

Figure 3: Cronbach Alpha overcome the threshold of 0.7, which is proving internal consistency reliability (Hair, et.al., 2014).

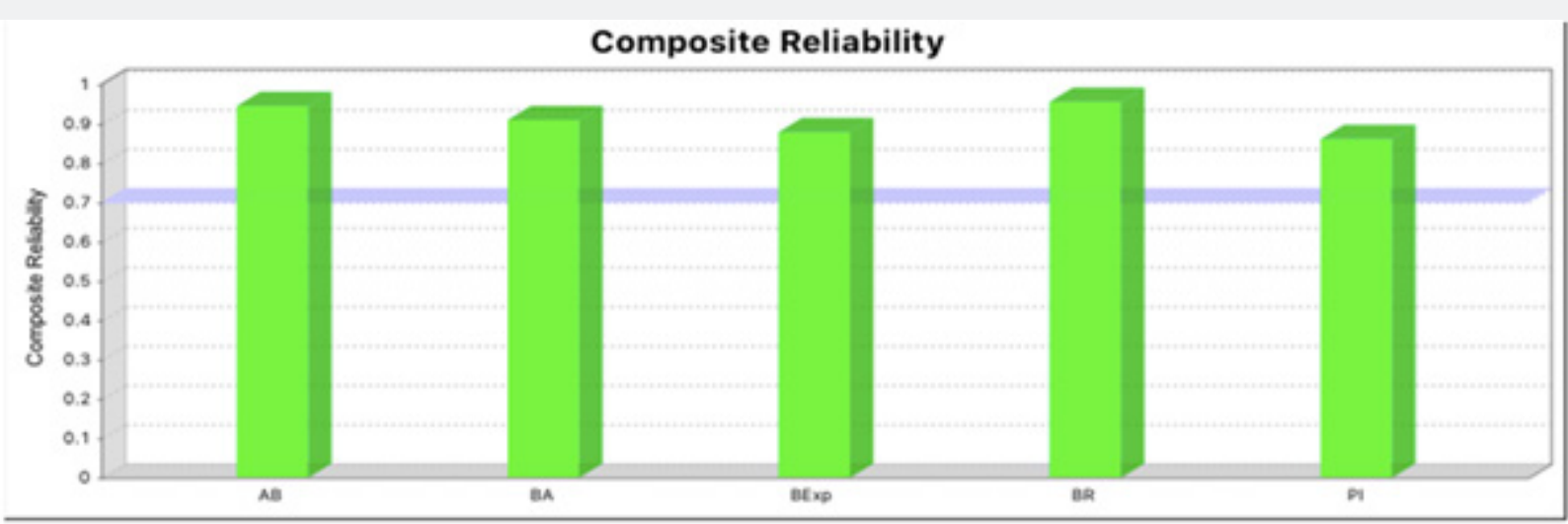

Figure 4: Composite Reliability. 
Discriminant validity is the extent to which a construct is truly distinct from other constructs by empirical standards. Thus, establishing implies that a construct is unique and cap?tures phenomena not represented by other constructs in the model. Two measures of discriminant validity have been proposed (Figure 6).

\begin{tabular}{|lrrrr|}
\hline & AB & BA & BExp & BR \\
\hline AB & 0.901 & & & \\
BA & 0.286 & 0.750 & & \\
BExp & 0.516 & 0.658 & 0.804 & 0.815 \\
BR & 0.453 & 0.877 & 0.729 & 0.749 \\
PI & 0.476 & 0.794 & 0.778 & \\
Figure 6: Fornell-Larcker Discriminant Validity. & & & \\
\hline
\end{tabular}

Assessment of the structural model results enables you to determine how well empirical data support the theory/ concept and therefore to decide if your theory/concept has been empirically confirmed. For this purpose, the key results (i.e., the path coefficients and R2 values) of the structural model are examined first.

The most commonly used measure to evaluate the structural model is the coefficient of determination (R-value). This coefficient-value measure of the model's predictive accuracy and is calculated as the squared correlation between a specific endogenous construct's actual and predicted values. The coefficient represents the exogenous latent variables' combined effects on the endogenous latent variable.
The $\mathrm{R} 2$ value ranges from 0 to 1 with higher levels indicating higher levels of predictive accuracy. It is difficult to provide rules of thumb for acceptable R2 values as this depends on the model complexity and the research discipline. Whereas R2 values of 0.20 are considered high in disciplines such as consumer behavior, in success driver studies (e.g., in studies that aim at explaining customer satisfaction or loyaalty), researchers expect much higher values of 0.75 and above (Figure 7 In scholarly research that focuses on marketing issues, R2 values of $0.75,0.50$, or 0.25 for endogenous latent variables can, as a rough rule of thumb, be respectively described as substantial, moderate, or weak (Hair, Ringle, \& Sarstedt, 2011; Henseler et al., 2009).

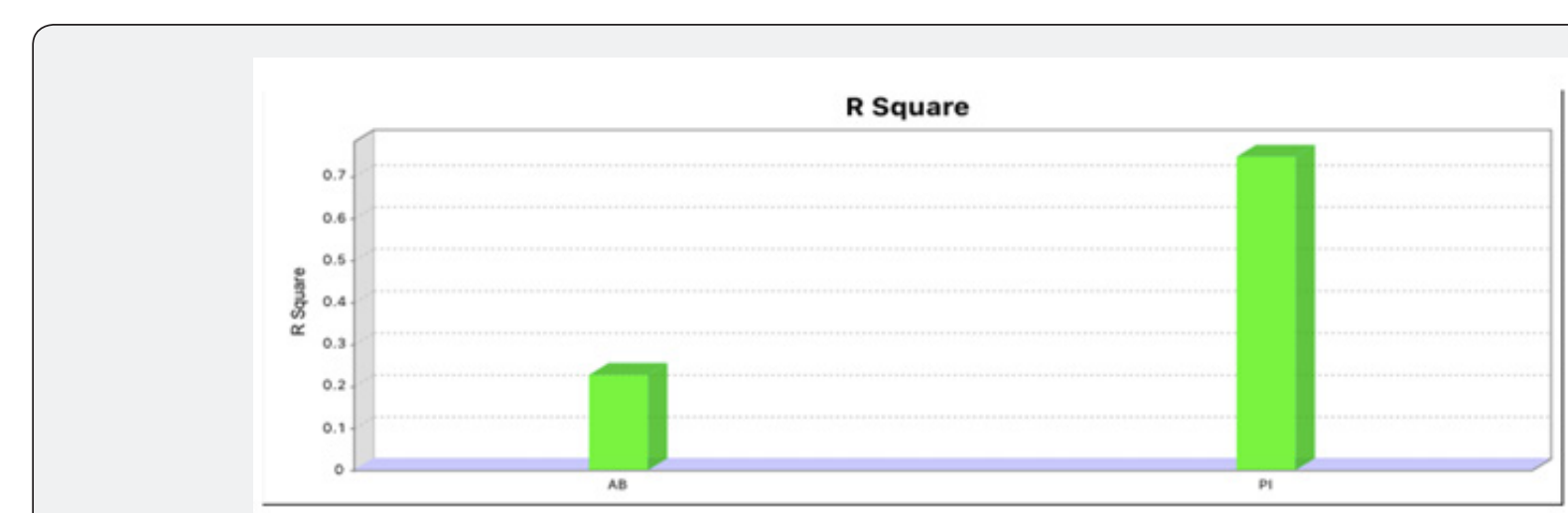

Figure 7: In scholarly research that focuses on marketing issues, $R 2$ values of $0.75,0.50$, or 0.25 for endogenous latent variables can, as a rough rule of thumb, be respectively described as substantial, moderate, or weak (Hair, Ringle, \& Sarstedt, 2011; Henseler et al., 2009).

Regarding Hypotheses testing, as shown in Figure 2.5 the analysis revealed the match significance level $\mathrm{p}<0.05$ for $\mathrm{H} 1, \mathrm{H} 2$, H4. Thus, can be stated that mentioned hypotheses are accepted.

Consequently, for $\mathrm{H} 3$ which is stated Attributes towards the brand experience which depends upon a brand relationshipbased experience impacts on purchase intention, the result is insignificant $p>0.05$, thus Hypothesis 3 is rejected (Figure 8).

Figure:2.7. Regarding Hypothesis 4 which is stated that Consumers' purchase intention towards the airline brand positively affects their actual behavior to buy the service, the level of significance as shown in Table $\mathrm{p}<0.05$, thus Hypothesis 4 is accepted (Figure 8). 
Annals of Social Sciences \& Management studies

\begin{tabular}{|c|c|c|c|c|c|}
\hline & Original Sample $(0$ & Sample Mean (M) & Standard Deviation (STDI & $S(\mid O / S T$ & P Values \\
\hline$B A \rightarrow P I$ & 0.556 & 0.545 & 0.116 & 4.788 & 0.000 \\
\hline BExp $>P I$ & 0.473 & 0.448 & 0.121 & 3.922 & 0.000 \\
\hline$B R \rightarrow P I$ & -0.083 & -0.047 & 0.160 & 0.523 & 0.601 \\
\hline$P I \Rightarrow A B$ & 0.476 & 0.484 & 0.101 & 4.711 & 0.000 \\
\hline
\end{tabular}

Figure 8: Regarding Hypothesis 4 which is stated that Consumers' purchase intention towards the airline brand positively affects their actual behavior to buy the service, the level of significance as shown in Table $p<0.05$, thus Hypothesis 4 is accepted (Figure 8 ).

\section{Discussion}

The result shows, in line with previous work, the influence of brand perception on actual buying from consumers has a positive and strong relation $[18,47]$. However, the current study shows that brand attitude has a positive and significant impact on purchase intention. Brand attitude, that included in the study brand association and brand belief shows absolute contribution. However, based on the analyses for relative importance consumers are doubt that the brand is up-market and had difficulties imagining the brand, which means that the brand difficult to remember or not remarkable.

A comprehensive study into the brand perception since the lockdown started indicates the pandemic has forever changed the structure of the company, forcing companies to prioritize the needs of consumers and employees to an unprecedented level.

Perception of the brand has shifted for customers, and companies suffer losses to how they are perceived.

Once the post-pandemic recovery begins, consumers are going to be mindful regarding their spending. Almost for a year airlines have been trying to outperform each other in offering a lower price, as a part of the contribution of post-pandemic recovery. Consumers expect that the price will dramatically drop. For the airlines besides the price, to attract the consumers in the future, should focus on proper management. The airline customers will pay attention to how the staff behaves during the boarding. When it comes to the appearance of the airline in public, consumers may dramatically change their perception. According to the result obtained brand reputation has a positive and significant impact on purchase intention [23]. However, the study shows that brand reputation along with brand reliability and brand benevolence is insignificant and does not have any impact on consumers' purchase intention.

Bran experience represents a distinct view and the quality of the brand to consumers. Therefore in this study brand experience was tested and showed a positive impact on purchase intention along with relationship-based experience. Absolute contribution showed all variables besides consumers are reluctant to buy tickets if it was recommended by their friends, which shows that the loyalty linked strongly to the consumers' experience.

The results reveal Malaysian makes brand function as their priority in purchase the airline's ticket. This result important for the airline industry to make sure to update their function or create a new function regularly to accommodate what their consumer need. For airlines, they should keep chasing the modern technology to be implemented in their business to make sure their customers are satisfied and focus on developing a new function that can help customers on time reduction for the whole purchasing process, boarding, landing and finally end of the journey. In the airline industry, the airline needs to have easy access to consumers. As passenger transport continues to expand, the futureproofing of its facilities is essential for airports (Future Travel Experience, 2019). All airlines have their mobile application, website, a self-service kiosk for check-in, and even self-service baggage check-in - all in the name of making consumer's life easier.

This result important for airlines to keep their service in check especially for staff at the counter and their steward and stewardess. Training needs to be regularly done to cater to different customers and different attitudes. This includes making their customer feel safe on the plane and trustworthy with their value for the whole process. A brand that can build a strong relationship is a brand that knows how to pursue the connection as it was a science, strategy, or even friendship [24]. The new media social work turns the traditional media communication from one way to a two-way conversation, which not only all the promotion run but to engage and create a real bond to the consumer (Rowles, 2014). According [6], product and services review online is one of the major touchpoints in brand perception as it is a way to influence people's decision and opinion about that product or services, even leaving the first impression to the new consumers. Social media play a very powerful channel to deliver brand effectiveness to consumers in a wide range of the market. Good customer service will keep a customer happy and a happy customer will create loyalty. Experience is one of the reasons a customer loyal to the airline. A brand that can build a strong relationship is a brand that knows how to pursue the connection as it was a science, strategy, or even friendship $[9,13]$. 
For brand reputation, it is the only negative in the results. The results may vary in other country but brand reputation results as negative is a bit of a turnaround point for Malaysians as they seem to not care about the reputation of their airlines [13]. According to Hussain et al., (2015), Corporate image can be defined as how the consumers reflect the brand in their memory, which is differentiated rate from their competitors. The more trust the airline can build, the more reputable they are [22]. For a brand to be profitable and prosperous, they need first to maintain a positive reputation and take it as something crucial in business [48]. The reputation of an organization needs to be monitored closely as it is one of the key success in business and it evolves all the time differently from time to time. The airlines might destroy their reputation by the major accident happen, but they did not destroy their service's reputation as they still doing their best despite the worst nightmares for the airline industry has happened. It is something that Malaysia's airline industry to be proud of as they still are preferable airlines no matter what happens to them.

Regarding brand experience, that showed is a positive result with purchase intention in Malaysia's international airline industry. According to Truong D, Pan, JY, Buaphiban T [14], a strong brand experience allows you to turn the whole experience well into an experience. It shows that their experience is important for them to make a decision. Their real encounter with the service might make another person purchase or not purchase the airline's ticket. Every experience has its own story to tell and none of them is similar in the sense that, a customer might feel that service for him/her is excellent but for others, it is just normal. Business Review (2015) sees greater customer satisfaction, diminished customer churn, higher revenue, and better employee satisfaction as the advantages of investing in the customer experience. By experience, the consumer always expects some change in every few years or every few encounters. Either it is an upgrade or downgrade experience, the business is fully responsible for it. Airlines need to make sure of a continuous excellent service given to all their customer and potential customers. They need to take their professionalism at check all the time to cater to everyone's experience to be a good one [49-53].

\section{Conclusion}

The current paper has presented an impact of brand perception: brand attitude, brand reputation brand experience on consumers' purchase intention, and the actual behavior of buying.

\section{Theoretical implication}

The challenges of brand perception influencing consumers' intention in a highly competitive industry, the introduced result of the current research contributes to strategic management in the airline industry in the novel several ways:

Firstly, the study demonstrates consumers perception of the brand, which airline companies need to focus on weak perception.
Secondly, the process of attitude toward brand and experience significantly impacts the airline companies' performance. Managers' capability to build a strong perspective around the brand will help to retain consumers' loyalty.

\section{Managerial application}

The study provides several managerial implications for the airline industry. Brand attitude and brand experience visibly indicate the impact on purchase intention. This should point as an advantage for the companies through providing an extra level of assurance, such as compulsory wearing a mask for consumers during the flight, as consequences consumers will experience a positive emotion towards airline company. Brand association for consumers may be established by providing more safety standards. The novel dimension of providing assurance will reflect the impact on staff development.

\section{Limitation and Future Direction}

The acknowledgment of the main limitation of the research and propose future research to address these limitations and extend the current study. Firstly, the current study involved a limited number of participants and not a comprehensive variety of different races. For future similar studies, it is recommended to wider the range of respondents and samples. It is recommended to find respondents from all fourteen states in Malaysia to get more accurate and better results in a future study. The future study also recommends using a variety of respondents from different races or maybe balance the race portion to be equal to each other to make sure it does not reflect only one race point of view. Race equality will produce a better result. This is to contribute the same buy behavior or equally. There is more in-depth knowledge if race equality can be achieved in future studies, therefore, it will produce more accurate data compared to this study.

Thirdly, the geography needs to be widened to make sure the results are the result of the opinion of the whole of Malaysia. The future study needs to include all respondents from fourteen different states to make sure everyone's opinion is included, and it comes from all parts of Malaysian to not be biased to only one area in Malaysia. Wider geographic data means more variety of opinion and more accuracy in terms of the results. Therefore, it is recommended to pick respondents from different states and make sure the amount is equal to each state.

Lastly, more variables need to be included in future studies. More variables can generate more results that are accurate. More accuracy in purchase intention can be explained from brand perception if more factors of brand perceptions can be added inside the study.

\section{References}

1. Archana R, Subha MV (2012) A study on service quality and passenger satisfaction on Indian airlines. International Journal of Multidisciplinary Research 2(2): 50-63. 


\section{Annals of Social Sciences \& Management studies}

2. Huang YC, Liu CH (2020) Buffering effects of brand perception to behavioural intention - Evidence of China airlines. Research in Transportation Business \& Management 37: 100468.

3. Al Saed R, Upadhya A, Abu Saleh M (2020) Role of airline promotion activities in destination branding: Case of Dubai vis-à-vis Emirates Airline. European Research on Management and Business Economics 26(3): 121-126

4. Sarker M, Mohd-Any AA, Kamarulzaman Y (2021) Validating a consumer-based service brand equity (CBSBE) model in the airline industry. Journal of Retailing and Consumer Services 59: 102354.

5. Sarkar A, Sarkar JG, Sreejesh S (2021) Managing customers' undesirable responses towards hospitality service brands during service failure: The moderating role of other customer perception. International Journal of Hospitality Management 94: 102873.

6. Han H, Lee KS, Chua BL, Lee S, Kim W (2019) Role of airline food quality, price reasonableness, image, satisfaction, and attachment in building re-flying intention. International Journal of Hospitality Management 80: 91-100.

7. Henderson IL, Tsui KWH, Ngo T, Gilbey A, Avis M (2019) Airline brand choice in a duopolistic market: The case of New Zealand. Transportation Research Part A: Policy and Practice 121: 147-163.

8. Valliappan Raju, Prof Dr. Md Rom Bin Tamjis (2019) Role of Sustainability in Marketing Strategies: In the Context of Digital and Direct Marketing, International Journal of Engineering and Technology 8(1.10).

9. Seo EJ, Park JW (2018) A study on the effects of social media marketing activities on brand equity and customer response in the airline industry. Journal of Air Transport Management 66: 36-41.

10. Chiu SC, Liu CH, Tu JH (2016) The influence of tourists' expectations on purchase intention: Linking marketing strategy for low-cost airlines. Journal of Air Transport Management 53: 226-234.

11. Shahzad IA, Raju V, Farrukh M, Kanwal N, Ikram M (2018) Quality of Work Life: A Significant Dimension of Non-Financial Compensation or Managers' Tool to Generate Reciprocity. International Journal of Human Resource Studies, 8(3).

12. Wang SW (2014) Do global airline alliances influence the passenger's purchase decision? Journal of Air Transport Management 37: 53-59.

13. Assoc Prof Dr Valliappan Raju, Dr Siew Poh Phung DN (2019) Exploratory Study on Aviation Sector's Decision-Making Process Pertaining to Marketing Information System. International Journal of Engineering \& Technology 8(1.10): 219-225.

14. Truong D, Pan JY, Buaphiban T (2020) Low cost carriers in Southeast Asia: How does ticket price change the way passengers make their airline selection? Journal of Air Transport Management 86: 101836

15. Slaton K, Testa D, Bakhshian S, Fiore AM (2020) The small, inventory free retail format: The impact on consumer-based brand equity and purchase behavior. Journal of Retailing and Consumer Services 57 102246

16. Lin Y, Ryan C (2016) From mission statement to airline branding. Journal of Air Transport Management 53: 150-160.

17. Uslu A, Durmuş B, Kolivar BK (2013) Analyzing the Brand Equity of Turkish Airlines Services: Comparing the Japanese and Turkish Perspectives. Procedia - Social and Behavioral Sciences 99: 446-454.

18. Woo E, Kim YG (2019) Consumer attitudes and buying behavior for green food products: From the aspect of green perceived value (GPV) British Food Journal 121(2): 320-332.
19. Shen C, Yahya Y (2021) The impact of service quality and price on passengers' loyalty towards low-cost airlines: The Southeast Asia perspective. Journal of Air Transport Management 91: 101966.

20. Chung YS, Feng CM (2016) Brand relationship between global airline alliances and their member airlines. Journal of Air Transport Management 55: 222-233.

21. Van Riel CB, Van den Ban A (2001) The added value of the corporate logos-An empirical study. Eur J Mark 35 (3/4): 428-440.

22. Hsiu Ying Kao G, Wang SW, Farquhar JD (2020) Modeling Airline Crisis Management Capability: Brand attitude, brand credibility, and intention. Journal of Air Transport Management 89.

23. Foroudi P (2018) Influence of brand signature, brand awareness, brand attitude, brand reputation on hotel industry's brand performance. International Journal of Hospitality Management 76: 271-285.

24. Wang XW, Cao YM, Park C (2019) The relationships among community experience, community commitment, brand attitude, and purchase intention in social media. International Journal of Information Management 49: 475-488.

25. Chen, Mei-Fang, Chia-Lin Lee (2015) The Impacts of Green Claims on Coffee Consumers' Purchase Intention. British Food Journal 117(1): 195-209.

26. Agmeka F, Wathoni RN, Santoso AS (2019) The Influence of Discount Framing towards Brand Reputation and Brand Image on Purchase Intention and Actual Behaviour in e-commerce. Procedia Computer Science 161: 851-858.

27. Kudeshia Chetna, Amresh Kumar (2017) Social eWOM: Does it Affect The Brand Attitude and Purchase Intention of Brands?. Management Research Review 40(3): 310-330.

28. Holbrook M, Batra R (1987) Assessing the role of emotions as mediators of consumer responses to advertising. The Journal of Consumer Research 14: 404-420.

29. Homer PM (1990) The mediating role of attitude toward the ad_some additional evidence. Journal of Marketing Research 27(1): 78-86.

30. Brett M, Wentzel D, Tomczak T (2008) Effects of susceptibility to normative influence and type of testimonial on attitudes toward print advertising. J Advert 37(1): 29-43.

31. Mitchell AA, Olson JC (1981) Are product attribute beliefs the only mediator of advertising effects on brand attitude? J Market Res 18(3): 318-332.

32. Delgado-Ballester E, Luis Munuera-Alemán J (2001) Brand trust in the context of consumer loyalty. Eur J Mark. 35 (11/12): 1238-1258.

33. DelVecchio D (2000) Moving beyond fit: the role of brand portfolio characteristics in consumer evaluations of brand reliability. J Prod Brand Manage 9(7): 457-471.

34. Lombart C, Louis D (2016) Sources of retailer personality: private brand perceptions. J Retail Consum Serv 28 (January): 117-125.

35. Spears N, Singh SN (2004) Measuring attitude toward the brand and purchase intentions. J Curr Issues Res Advertising 26(2): 53-66.

36. Sirdeshmukh D, Singh J, Sabol B (2002) Consumer trust, value, and loyalty in relational exchanges. J Mark 66 (1): 15-37.

37. Xie Y, Peng S (2009) How to repair customer trust after negative publicity: The roles of competence, integrity, benevolence, and forgiveness. Psychol Mark 26(7): 572-589.

38. Zhao L, Roper J (2011) A Confucian approach to well-being and social capital development. J Manage Dev 30 (7/8): 740-752. 


\section{Annals of Social Sciences \& Management studies}

39. Low KC, Ang SL (2013) Confucian ethics, governance, and corporate social responsibility. Int J Bus Manage 8 (4): 30-44.

40. Kang J, Tang L, Fiore AM (2014) Enhancing consumer-brand relationships on restaurant Facebook fan pages: Maximizing consumer benefits and increasing active participation. International Journal of Hospitality Management 36: 145-155.

41. Shao, Pan (2019) Building Guanxi network in the mobile social platform: A social capital perspective. International Journal of Information Management 44: 109-120.

42. Grewal D, Krishnan R, Baker J, Borin N (1998) The effect of store name, brand name, and price discounts on consumers' evaluations and purchase intentions. Journal of Retailing 74(3): 331-352.

43. Wee, Chiew Shi, Mohd Shoki Bin Md Ariff, Norhayati Zakuan, Muhammad Naquib Mohd Tajudin, Khalid Ismail, and Nawawi Ishak (2014) Consumers Perception, Purchase Intention and Actual Purchase Behavior of Organic Food Products. Review of Integrative Business and Economics Research 3(2): 378-397.

44. Hair JF, Black William C, Babin Barry J, Anderson, Rolph E, Tatham Roland L, (2006) Multivariate Data Analysis. Pearson, New Jersey, United States.

45. Nunnally J (1978) Psychometric Theory. McGraw-Hill, New York United States.

46. Bagozzi RP, Yi Y (1988) On the evaluation of structural equation modeling. J Acad Market Sci 16 (1): 74-94.

47. Medina-Molina C, Rey-Moreno M, Periáñez-Cristóbal R (2021) Analysis of the moderating effect of front-of-pack labeling on the relation between brand attitude and purchasing intention. Journal of Business Research 122: 304-310.

48. Santos de Oliveira D, Caetano M (2019) Market strategy development and innovation to strengthen consumer-based equity: The case of Brazilian airlines. Journal of Air Transport Management 75: 103-110.

49. Al Saed R, Upadhya A, Abu Saleh M (2020) Role of airline promotion activities in destination branding: Case of Dubai vis-à-vis Emirates Airline. European Research on Management and Business Economics 26(3): 121-126

50. Bhandari M, Rodgers S, Pan P (2020) Investigating Brand Feedback in eWOM Messages: Effects of Stability and Controllability of Problem Causes on Brand Attitude and Purchase Intention. Telematics and Informatics, 101522.

51. Valliappan Raju, Dr Siew Poh Phung, Dr Sivashankar Factors Determining Malaysian SMEs Performance in Knowledge Management. International Journal of Engineering and Technology 8(1.10).

52. Wang SW, Hsu MK (2016) Airline co-branded credit cards-An application of the theory of planned behavior. Journal of Air Transport Management 55: 245-254.

53. Alhajjar A, Vorobyova K, Alrifai AA, Kassim RM, Teknologi U, et al. (2020) The Mediating Effect of Employee Commitment on the Relationship between Talent Management, Reward System, and Bank Performance, The International Academy of Strategic Research, Malaysia. Journal of Advanced Research in Business, Marketing, and Supply Chain Management.

Your next submission with Juniper Publishers
will reach you the below assets
- Quality Editorial service
- Swift Peer Review
- Reprints availability
- E-prints Service
- Manuscript Podcast for convenient understanding
- Global attainment for your research
- Manuscript accessibility in different formats
( Pdf, E-pub, Full Text, Audio)
- Unceasing customer service
Track the below URL for one-step submission
https://juniperpublishers.com/online-submission.php

